\title{
A Rapid and Simple Multiparameter Assay to Quantify Spike-Specific CD4 and CD8 T Cells after SARS-CoV-2 Vaccination: A Preliminary Report
}

\author{
Mojtaba Shekarkar Azgomi 1,2®, Marco Pio La Manna 1,2, Giusto Davide Badami 1,2®, Paolo Ragonese ${ }^{2}$, \\ Antonino Trizzino ${ }^{3}$, Francesco Dieli ${ }^{1,2}$ (D) and Nadia Caccamo ${ }^{1,2, *(D)}$ \\ 1 Central Laboratory of Advanced Diagnostic and Biomedical Research (CLADIBIOR), University of Palermo, \\ 90127 Palermo, Italy; mojtaba.shekarkarazgomi@unipa.it (M.S.A.); marcopio.lamanna@unipa.it (M.P.L.M.); \\ giustodavide.badami@unipa.it (G.D.B.); francesco.dieli@unipa.it (F.D.) \\ 2 Department of Biomedicine, Neurosciences and Advanced Diagnostic (Bi.N.D.), University of Palermo, \\ 90127 Palermo, Italy; paolo.ragonese@unipa.it \\ 3 Department of Pediatric Hematology and Oncology, A.R.N.A.S. Civico Di Cristina and Benfratelli Hospital, \\ 90127 Palermo, Italy; triznino@hotmail.com \\ * Correspondence: nadia.caccamo@unipa.it
}

Citation: Azgomi, M.S.; La Manna M.P.; Badami, G.D.; Ragonese, P.; Trizzino, A.; Dieli, F.; Caccamo, N. A Rapid and Simple Multiparameter Assay to Quantify Spike-Specific CD4 and CD8 T Cells after SARS-CoV-2 Vaccination: A Preliminary Report. Biomedicines 2021, 9, 1576. https:/ / doi.org/10.3390/biomedicines9111576

Academic Editors:

Pasquale Ambrosino and

Mauro Maniscalco

Received: 24 September 2021

Accepted: 27 October 2021

Published: 29 October 2021

Publisher's Note: MDPI stays neutral with regard to jurisdictional claims in published maps and institutional affiliations.

Copyright: (c) 2021 by the authors. Licensee MDPI, Basel, Switzerland. This article is an open access article distributed under the terms and conditions of the Creative Commons Attribution (CC BY) license (https:// creativecommons.org/licenses/by/ $4.0 /)$
Abstract: mRNA and Adenovirus vaccines for COVID-19 are used to induce humoral and cellmediated immunity, with the aim to generate both SARS-CoV-2 B and T memory cells. In present study, we described a simple assay to detect and quantify Spike-specific CD4 ${ }^{+}$and $\mathrm{CD} 8^{+} \mathrm{T}$ cell responses induced by vaccination in healthy donors and in subjects with B cell compart impairment, in which antibody response is absent due to primary immunodeficiencies or CD20 depleting therapy. We detect and quantified memory $\mathrm{T}$ cell immune responses against SARS-CoV-2 evocated by vaccination in both groups, irrespective to the humoral response. Furthermore, we identified TNF- $\alpha$ as the main cytokine produced by T memory cells, after antigen-specific stimulation in vitro, that could be considered, other than IFN- $\gamma$, an additional biomarker of induction of $\mathrm{T}$ memory cells upon vaccination. Further studies on the vaccine-induced $\mathrm{T}$ cell responses could be crucial, not only in healthy people but also in immunocompromised subjects, where antigen specific $\mathrm{T}$ cells responses play a protective role against SARS-CoV-2.

Keywords: Pfizer/BioNTech; memory T cell; $\mathrm{CD}^{+}{ }^{+} \mathrm{CD}^{+}$; SARS-CoV-2; cytokines

\section{Introduction}

After more than 2 years, a syndrome case by severe acute respiratory syndrome coronavirus 2 (SARS-CoV-2) has caused more than 4 million deaths worldwide, and it still is a prevalent outbreak [1]. To date, different licensed vaccines for COVID-19 with different techniques are available, and all presumably induce both humoral and cell-mediated immunity, both of which are required for recovery following SARS-CoV-2 infection. In addition, patients with more severe diseases develop neutralizing antibodies (NAb) that correlate with viral load [2,3]. Still, on the other hand, SARS-CoV-2 can spread from cell to cell without exposure to the extracellular environment [4], limiting the role of NAb in reducing viral spread within the host. For this reason, T cells could be important mediators of the protective host response to SARS-CoV-2 infection. Hence, there is an urgent need to consider the role of SARS-CoV-2-specific $\mathrm{T}$ cell immune response after vaccination, analyzing either $\mathrm{CD}^{+} \mathrm{T}$ cells, which help $\mathrm{B}$ cells for antibody production, or $\mathrm{CD} 8^{+} \mathrm{T}$ cells that kill virus-infected cells [5,6]. Therefore, a simple and rapid assessment of $\mathrm{T}$ cell immune response after vaccination remains a challenge. Using flow cytometry, Riou and colleagues described a rapid assay to qualitatively and quantitatively measure SARS-CoV-2-specific $\mathrm{CD}^{+}{ }^{+} \mathrm{T}$ cell responses in 31 healthcare workers [7]. Despite several studies demonstrating the feasibility of detecting SARS-CoV-2-specific $\mathrm{CD}^{+}$and $\mathrm{CD}^{+} \mathrm{T}$ cells, most of them 
have been performed in SARS-CoV-2-infected individuals and using different techniques. Still, there is very limited knowledge on similar assays performed after vaccination. Here, we report a rapid ( 18 h) method to monitor SARS-CoV-2-specific T cell responses after vaccination independently from NAb blood concentration, which is alsousable in patients with primary or secondary B cell defects.

\section{Methods}

This assay relies on simultaneous expression of three cytokines (IL-2, IFN- $\gamma$ and TNF- $\alpha$ ) after $18 \mathrm{~h}$ of stimulation in vitro with a pool of lyophilized peptides, consisting mainly of 15-mer sequences with an 11 amino acid overlap, covering the immunodominant sequence domains of the spike glycoprotein of SARS-CoV-2 (PepTivator ${ }^{\circledR}$ SARS-CoV-2 Prot_S, Miltenyi Biotec, Surrey, UK). The study was approved by the Ethical Committee of the University Hospital. Peripheral blood mononuclear cells (PBMCs) were obtained from $n=41$ fully vaccinated (mRNA vaccine BNT162b2, Pfizer/BioNTech, Mangonza, Germany) individuals, 15 to 21 days after receiving the second dose vaccine. Asymptomatic subjects negative for SARS-CoV-2 with a real-time PCR test were enrolled in the study.

The enrolled subjects $(n=40)$, were divided into four groups; the first three groups were composed of healthy donors $(n=28)$ with different titers of SARS-CoV-2 NAbs (SARSCoV-2 Trimeric S IgG) at the time of venipuncture: G1 with a level of NAb $<390 \mathrm{BAU} / \mathrm{mL}$, G2 with $390<\mathrm{NAb}<1040 \mathrm{BAU} / \mathrm{mL}$, G3 with NAb > $1040 \mathrm{BAU} / \mathrm{mL}$. The fourth group (G4) was composed of patients $(n=12)$ without functional B cells and no NAb in peripheral blood (six patients with multiple sclerosis in therapy with ocrelizumab and six patients with primitive $B$ cell deficiencies). The demographic characteristics of the groups are reported in Table 1 while the specific clinical and therapeutic characteristics of G4 patients are reported in Table 2.

Table 1. Characteristics of enrolled subjects.

\begin{tabular}{|c|c|c|c|c|c|c|c|c|c|c|}
\hline \multirow[b]{2}{*}{ Enrolled Subjects (\%) } & \multicolumn{2}{|c|}{$\begin{array}{c}\text { G1 HD, } \\
\mathrm{Nab}<390 \\
\text { BAU/mL }\end{array}$} & \multicolumn{2}{|c|}{$\begin{array}{c}\text { G2 HD, } \\
390<\mathrm{Nab}<1040 \\
\text { BAU } / \mathrm{mL}\end{array}$} & \multicolumn{2}{|c|}{$\begin{array}{c}\text { G3 HD, } \\
\text { Nab > 1040 } \\
\text { BAU } / m L\end{array}$} & \multicolumn{2}{|c|}{$\begin{array}{l}\text { G4 Patients } \\
\text { Ocrelizumab or } \\
\text { Primitive } \\
\text { B Cell } \\
\text { Deficiences }\end{array}$} & \multicolumn{2}{|c|}{ Total } \\
\hline & 9 & $(22.5 \%)$ & 8 & $(20 \%)$ & 11 & $(27.5 \%)$ & 12 & $(30 \%)$ & 40 & $(100 \%)$ \\
\hline Mean Age & 50 & & 44 & & 45 & & 41 & & 44 & \\
\hline Range & $27-66$ & & $27-59$ & & $22-55$ & & $21-64$ & & $22-66$ & \\
\hline Male Gender (\%) & 5 & $(55.7 \%)$ & 3 & $(37.5 \%)$ & 3 & $(77.5 \%)$ & 3 & $(27.3 \%)$ & 14 & $(35 \%)$ \\
\hline
\end{tabular}

PBMCs were stimulated for $18 \mathrm{~h}$ at $37{ }^{\circ} \mathrm{C} 5 \% \mathrm{CO}_{2}$ in RPMI 1640 complete medium, witha spike-specific peptide pool $(1 \mu \mathrm{g} / \mathrm{mL})$ at $1 \times 10^{6}$ cells $/ \mathrm{mL}$. RPMI or ionomycin/PMA were included in each sample as negative or positive controls, respectively. Brefeldin-A $(10 \mu \mathrm{g} / \mathrm{mL})$ was added after $2 \mathrm{~h}$.

After $18 \mathrm{~h}$ of stimulation, cells were harvested and stained, first with live/dead marker (Zombie dye, Biolegend San Diego, CA, USA) then with mAb anti-human CD3PerCP-Vio ${ }^{\circledR}$ 700, mAb anti-human CD4 PE-Vio ${ }^{\circledR} 770$ and mAb anti-human CD8 APC. After surface staining, cells were fixed, permeabilized and stained at room temperature for $30 \mathrm{~min}$ with $\mathrm{mAb}$ to anti-human IL-2 APC-Vio ${ }^{\circledR} 770, \mathrm{mAb}$ anti-human IFN- $\gamma$ FITC and $\mathrm{mAb}$ anti-human TNF- $\alpha$ PE. Samples were acquired on a FACSARIA II flow cytometer (BD Bioscience San Jose CA, USA) and analyzed using FlowJo v10 (BD Bioscience San Jose CA, USA).

The gating strategy is shown in Figure 1A. The threshold for positivity for spikespecific $\mathrm{CD} 4^{+} \mathrm{T}$ cell responses $(>0.02 \%)$ and antigen-specific $\mathrm{CD} 8^{+} \mathrm{T}$ cell responses $(>0.05 \%)$ was set according to Dan et al. [7-9] and calculated using the median two-fold standard deviation of all negative controls measured. GraphPad software was used to perform statistical analysis, and the groups were analyzed by using a Kruskal-Wallis test with Dunn's correction and a Pearson correlation test. 


\section{Figure 1}

A
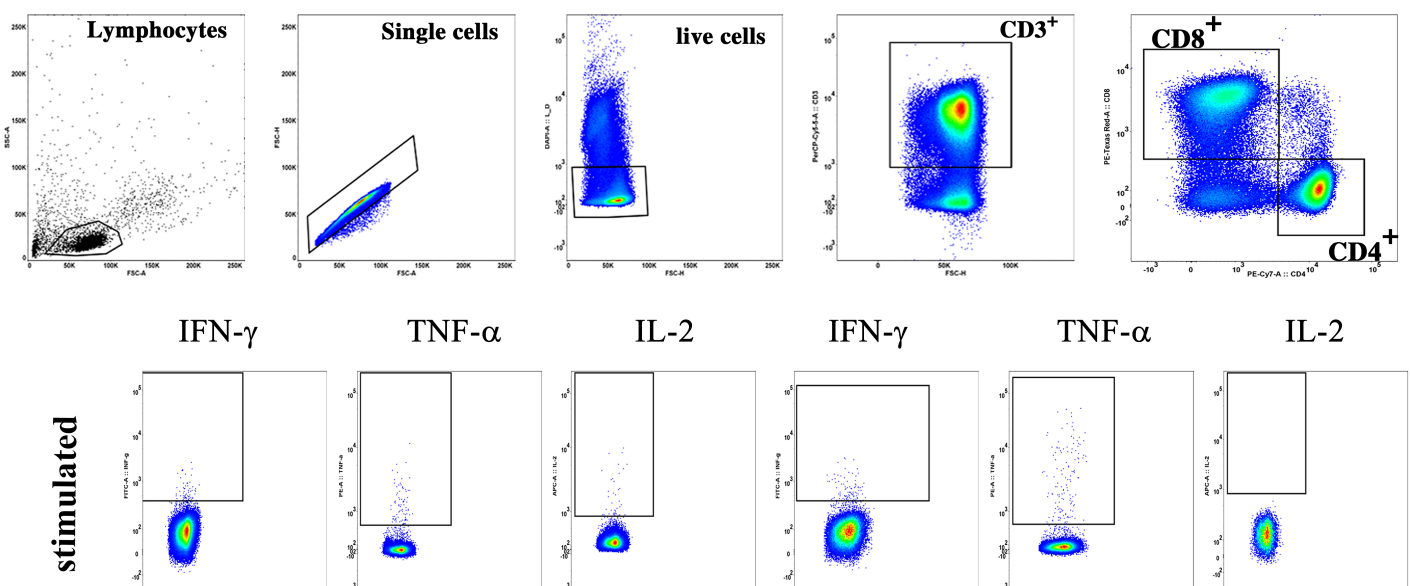

TNF- $\alpha$
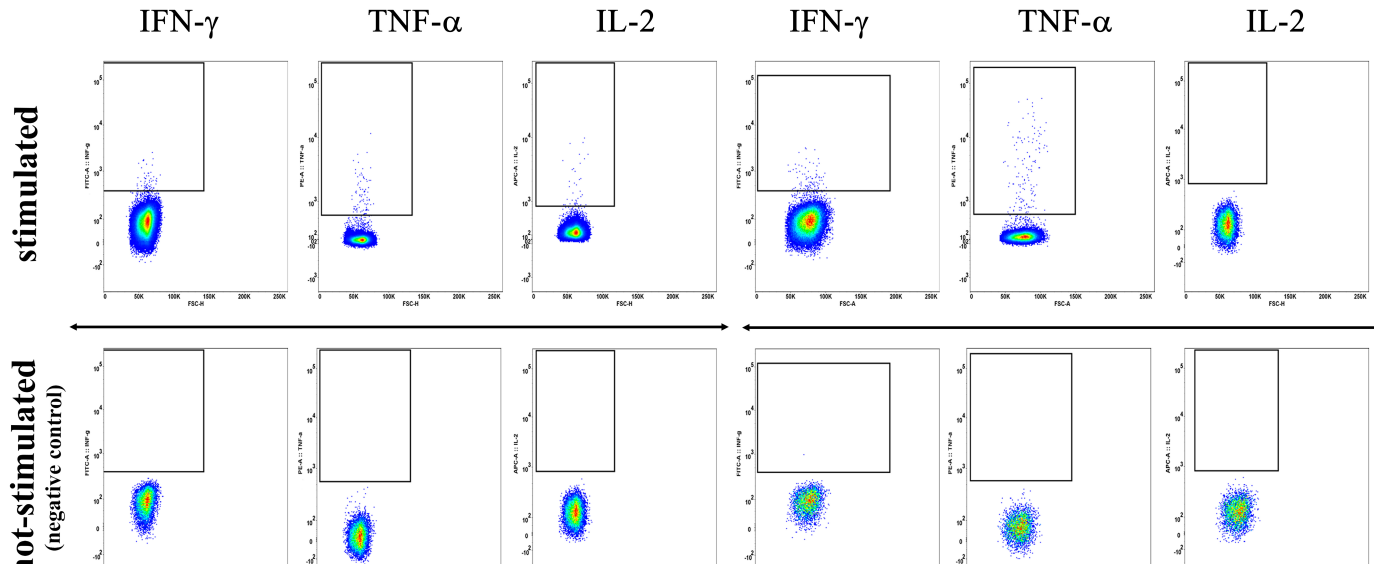

?.
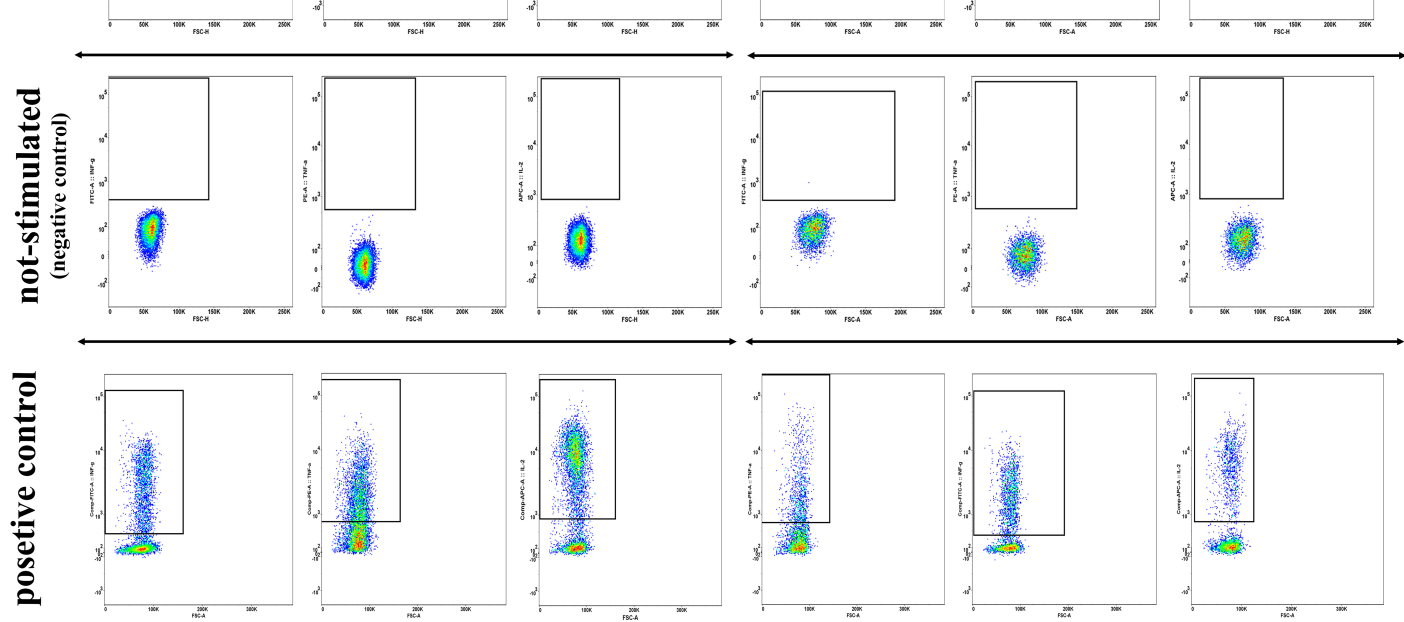
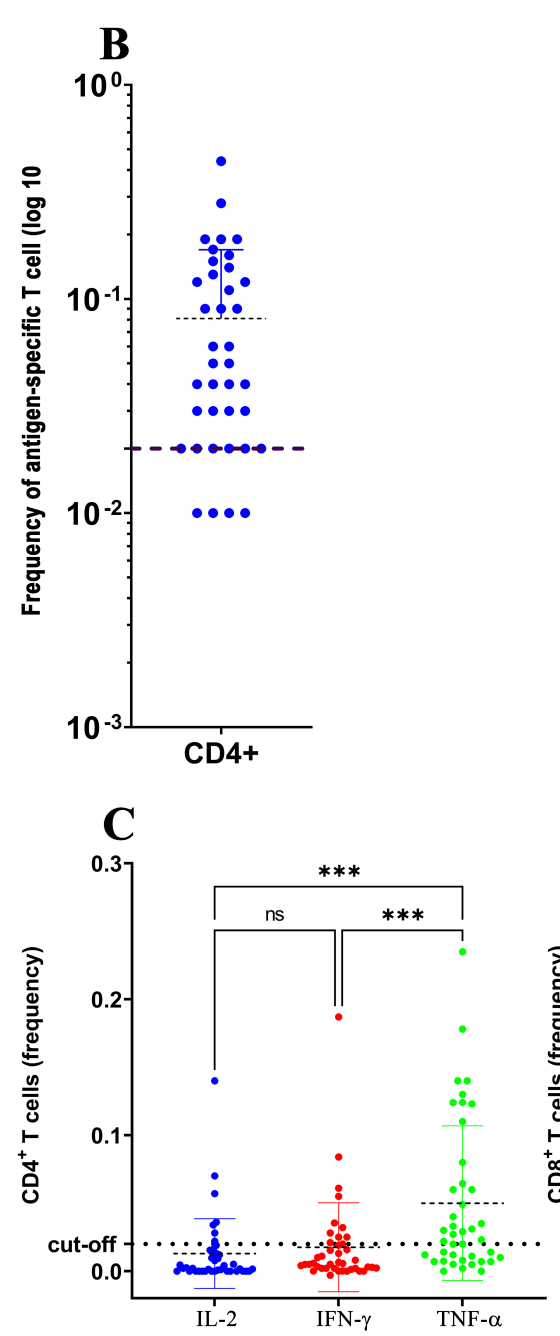
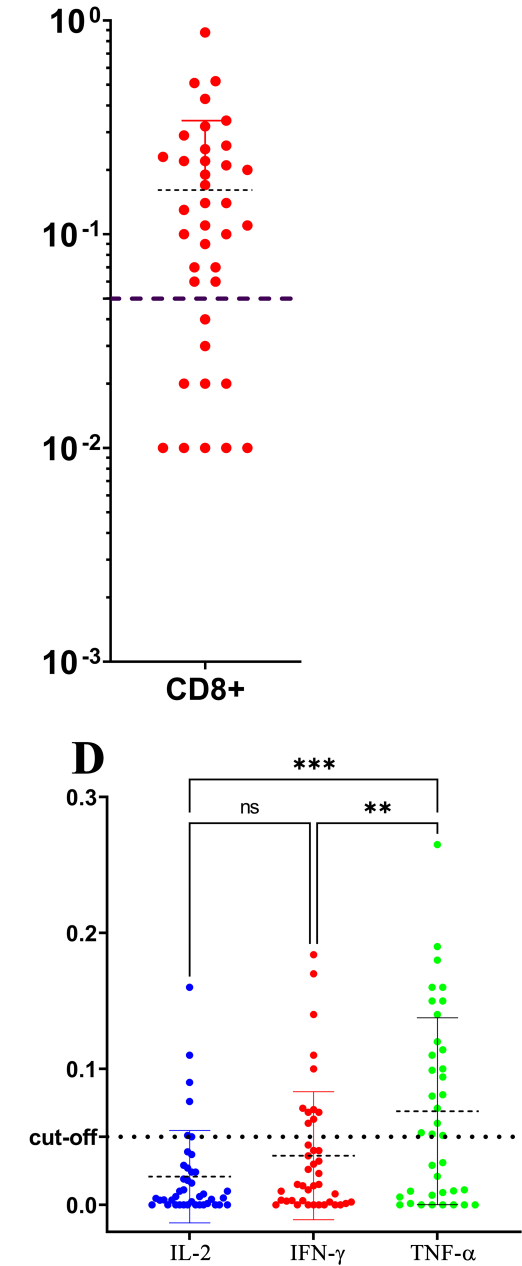

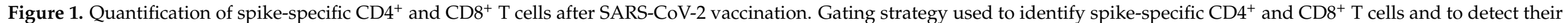

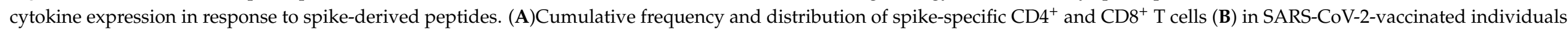

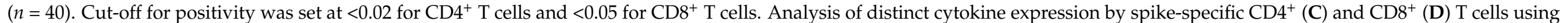
Kruskal-Wallis test with Dunn's correction. ${ }^{* *} p<0.01$; ${ }^{* * *} p<0.001$; ns: not significant. 
Table 2. Clinical and therapeutic characteristics of G4 enrolled patients.

\begin{tabular}{|c|c|c|c|c|c|}
\hline G4 Enrolled Patients & Pathology & CCI & Therapy & N Days & IgG mg/dL \\
\hline ID20 & RRMS & 0 & Ocrelizumab & 180 & - \\
\hline ID30 & RRMS & 0 & Ocrelizumab & 180 & - \\
\hline ID31 & RRMS & 0 & Ocrelizumab & 180 & - \\
\hline ID39 & RRMS & 1 & Ocrelizumab & 160 & - \\
\hline ID40 & SPMS & 2 & Ocrelizumab & 180 & - \\
\hline ID41 & RRMS & 0 & Ocrelizumab & 180 & - \\
\hline ID25 & CVID & - & $\begin{array}{l}\text { IgG Vein } \\
\text { Kendrion }\end{array}$ & 28 & $>600$ \\
\hline ID38 & CVID & - & $\begin{array}{c}\text { Subcutaneous IgG } \\
\text { Hyqvia Takeda }\end{array}$ & 28 & $>600$ \\
\hline ID45 & XLA & - & $\begin{array}{c}\text { Subcutaneous IgG } \\
\text { Hyqvia Takeda }\end{array}$ & 28 & $>600$ \\
\hline ID46 & CIVD & - & $\begin{array}{c}\text { CSL Bhering } \\
\text { Hizentra }\end{array}$ & 15 & $>600$ \\
\hline ID47 & XLA & - & $\begin{array}{l}\text { IgG Vein } \\
\text { Kendrion }\end{array}$ & 28 & $>600$ \\
\hline ID48 & $\mathrm{PNH}$ & - & $\begin{array}{l}\text { CSL Bhering } \\
\text { Hizentra }\end{array}$ & 15 & $>600$ \\
\hline
\end{tabular}

RRMS = Relapsing-remitting multiple sclerosis;SPMS = Secondary progressive multiple sclerosis; CVID = Common variable immunodeficiency; XLA = Bruton'sagammaglobulinemia;PNH = Paroxysmal nocturnal hemoglobinuria;CCI = Charlson comorbidity index; $\mathrm{N}$ days $=$ Days from the last infusion of monoclonal $\mathrm{Ab}$ or human IgG with respect to the sampling day.

\section{Results}

The proportion of vaccinated subjects positive for spike-specific memory $\mathrm{CD} 4^{+}$and $\mathrm{CD} 8^{+} \mathrm{T}$ cells, measured as the frequency of $\mathrm{CD} 4^{+}$and $\mathrm{CD} 8^{+} \mathrm{T}$ cells simultaneously expressing IL-2, IFN- $\gamma$ and TNF- $\alpha$, was $90 \%(36 / 40)$ and $70 \%(28 / 40)$, respectively (Figure $1 \mathrm{~B})$. Indeed, both the spike-specific $\mathrm{CD} 4^{+}$and $\mathrm{CD} 8^{+}$responses were characterized by very faint (if any) IL-2 expression and very low IFN- $\gamma$ expression, but were enriched in cells expressing TNF- $\alpha$ (Figure 1C,D). Thus, and also in agreement with the study of Riou and colleagues [7], in our assay, TNF- $\alpha$ was the predominant cytokine produced, either by spike-specific $\mathrm{CD} 4^{+}$or $\mathrm{CD} 8^{+} \mathrm{T}$ cells, suggesting that TNF- $\alpha$ could be a more reliable biomarker than any other cytokine to detect spike-specific $\mathrm{T}$ cells in response to vaccination.

To study the correlation between the spike-specific $\mathrm{T}$ cell response and the NAb response, we stratified vaccinated healthy donors into three groups according to the titer of SARS-CoV-2NAbs: G1, <390 BAU/mL; G2, 390-1040 BAU/mL; G3, >1040 BAU/mL.

As shown in Figure $2 \mathrm{~A}, \mathrm{~B}$, the spike-specific $\mathrm{CD} 4^{+}$and $\mathrm{CD} 8^{+}$responses were of similar magnitude irrespective of the NAb titers in the G1, G2 and G3 groups. Accordingly, we did not find significant correlation between frequencies of spike-specific $\mathrm{CD} 4^{+}$and $\mathrm{CD} 8^{+} \mathrm{T}$ cells with NAb titers (Figure 2C,D), at least limited to those vaccinated subjects for whom precise antibody titers were available.

Finally, we analyzed the spike-specific $\mathrm{T}$ cell response in a group of subjects affected by primary or secondary B cell deficiencies, that had been vaccinated with the Pfizer/BioNTech BNT162b2 mRNA vaccine. Despite failing to produce spike-specific antibodies (Table 3), the B cell-deficient subjects showed a measurable spike-specific $\mathrm{T}$ cell response, comparable with that of the other groups. 

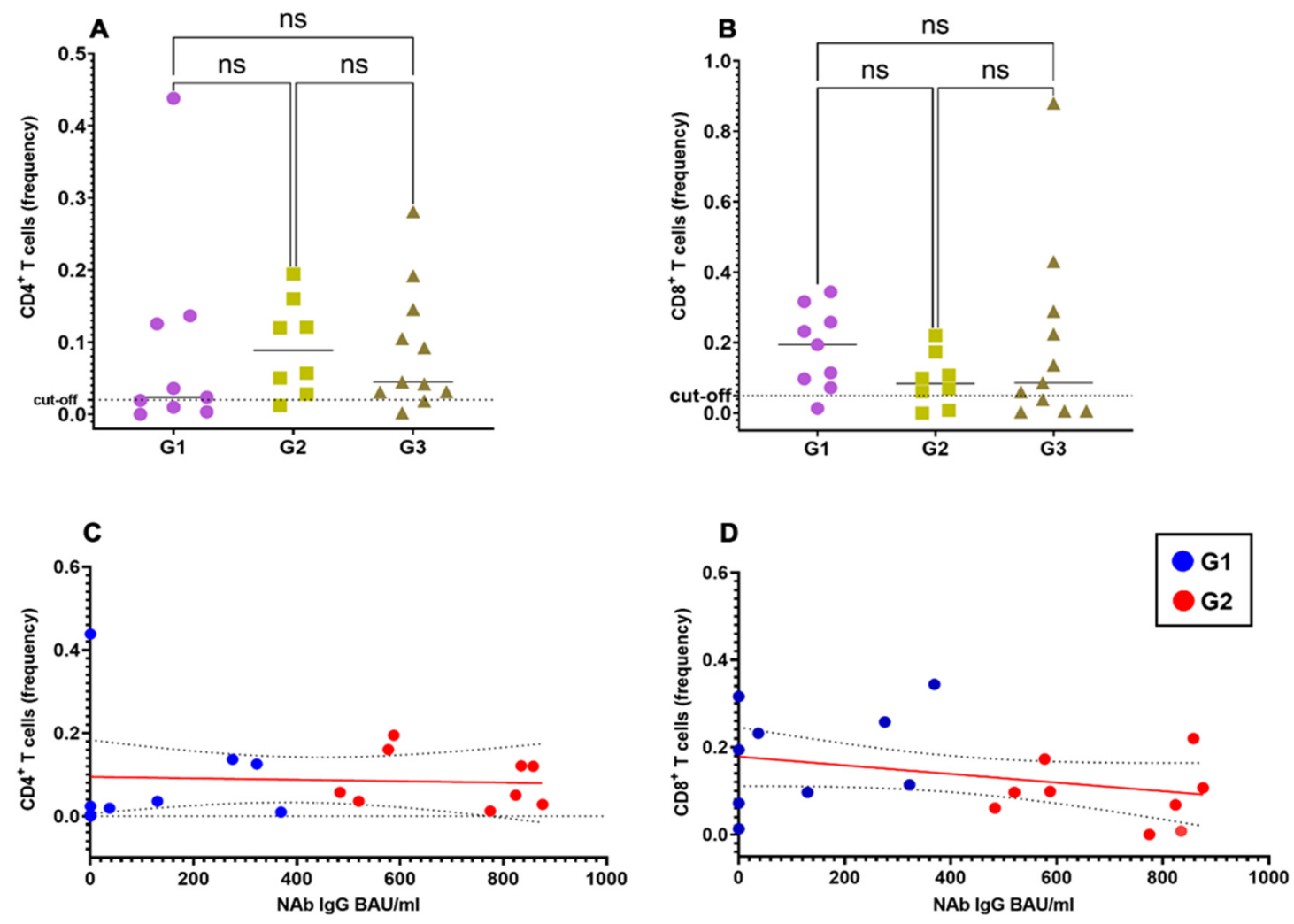

Figure 2. Correlation of spike-specific $\mathrm{CD} 4^{+}$and $\mathrm{CD} 8^{+} \mathrm{T}$ cells with spike-specific NAb titers. Frequencies of spike-specific $\mathrm{CD}^{+}(\mathbf{A})$ and $\mathrm{CD}^{+}(\mathbf{B})$ T cells upon stratification of vaccinated individuals in 3 different groups according to their SARSCoV-2 NAb titers (groups G1 to G3). Pearson correlation coefficient with one-tailed P-value and $90 \%$ confidence interval between titers of SARS-CoV-2 NAbs and the frequency of spike-specific CD4 ${ }^{+}(\mathbf{C})$ and CD8 ${ }^{+}(\mathrm{D}) \mathrm{T}$ cells.

Table 3. NAb titer and frequency of responder T cells in patients with B cell deficiencies.

\begin{tabular}{cccc}
\hline Enrolled Patients & NAb BAU /mL & $\begin{array}{c}\text { Frequency }(\%) \text { of } \\
\text { CD4 } 4^{+} \text {T Cells }\end{array}$ & $\begin{array}{c}\text { Frequency (\%) of } \\
\text { CD8 }{ }^{+} \text {T Cells }\end{array}$ \\
\hline ID20 & 0 & $\mathbf{0 . 0 5 5 8}$ & 0.0174 \\
ID25 & 0 & $\mathbf{0 . 1 9 3 3}$ & $\mathbf{0 . 2 0 6 9}$ \\
ID30 & 0 & $\mathbf{0 . 0 2 7 1}$ & 0.0136 \\
ID31 & 0 & $\mathbf{0 . 0 6 0 0}$ & $\mathbf{0 . 5 2 3 2}$ \\
ID38 & 0 & $\mathbf{0 . 0 3 5 0}$ & 0.0256 \\
ID39 & 0 & 0.0021 & $\mathbf{0 . 1 2 8 5}$ \\
ID40 & 0 & $\mathbf{0 . 0 3 9 0}$ & 0.0230 \\
ID41 & 0 & $\mathbf{0 . 0 8 6 7}$ & $\mathbf{0 . 0 6 3 1}$ \\
ID45 & 0 & $\mathbf{0 . 0 3 5 9}$ & $\mathbf{0 . 0 9 6 9}$ \\
ID46 & 0 & 0.0120 & $\mathbf{0 . 5 1 0 9}$ \\
ID47 & 0 & $\mathbf{0 . 1 7 0 0}$ & $\mathbf{0 . 1 4 4 0}$ \\
ID48 & 0 & 0.0120 & $\mathbf{0 . 2 5 3 0}$ \\
\hline
\end{tabular}

Values above the cut-off are indicated in bold.

\section{Discussion}

Much scientific evidence suggests that the cell-mediated response assumes relevant importance for an effective immune response against SARS-CoV-2 virus [10]. One study, in particular, showed that in cancer patients, the establishment of the cell-mediated response induced by the vaccine, even in the absence of a corresponding antibody response, was sufficient to confer protection against infection [11]. Another study has highlighted the establishment of the cellular immune response against SARS-CoV-2 in subjects vaccinated with BNT162b2Pfizer/BioNTech in the absence of an antibody response at the time of the assessment of adaptive immunity, after the second injection [12]. Furthermore, many 
studies have shown that mRNA vaccines induced a reduced humoral response in patients with acquired immunodeficiencies due to hematological diseases [13] or immunosuppressive therapies, including the use of biological drugs such as rituximab [14,15]. Finally, the Pfizer vaccine also provokeda cell-mediated immune response in subjects with primary immunodeficiencies affecting the B compartment [16]. This literature shows the potential usefulness of a test to evaluate the efficacy of vaccination by measuring the cellular immune response.

Some attempts have been made in this direction, also considering evaluating IFN$\gamma$ using IGRA tests [17]. However, the T cells' response is expressed through different activation pathways, and the evaluation of a single cytokine may not fully reflect the state of activation of this compartment. A multiparametric flow cytometry test, such as the one proposed in this communication, through the evaluation of the simultaneous expression of TNF- $\alpha$, IL2 and IFN- $\gamma$ can identify more completely the presence of a cell-mediated immune response induced by vaccination regardless of the evaluation of the humoral response.

Our study shows that vaccination with Pfizer gives a robust cell-mediated immunological memory against spike protein antigens, independently from the titer of NAb, meaning that the $\mathrm{T}$ cell-mediated specific immune response against SARS-CoV-2 caused by vaccination can develop independently from B cell response. This finding highlights the importance of the cell-mediated immunity against SARS-CoV-2 induced by vaccination and identifies TNF- $\alpha$ as the main product of T cells of vaccinated subjects after specific stimulation in vitro, making this cytokine a correlate of successful vaccination. In conclusion, we have reported a proof-of-concept study describing a simple and easy assay to detect and quantify spike-specific $\mathrm{CD} 4^{+}$and $\mathrm{CD} 8^{+} \mathrm{T}$ cell responses induced by vaccination. Although our study has many limitations (small number of tested individuals, optimization and validation), it provides a tool to monitor the immunogenicity of SARS-CoV-2 vaccines and study the correlation between the quantity and quality of $\mathrm{B}$ and $\mathrm{T}$ cell-mediated responses and protection. Finally, studying vaccine-induced $T$ cell responses may be of value in those subjects with B cell depletion following ocrelizumab or due to primary immunodeficiencies, in which serological responses are impaired, but $\mathrm{T}$ cell responses are preserved.

Author Contributions: Conceptualization, M.P.L.M., N.C. and F.D.; methodology, M.S.A.; software, M.S.A.; validation, N.C. and F.D.; formal analysis, M.S.A. and M.P.L.M.; investigation, M.S.A., G.D.B. and M.P.L.M.; resources, F.D., P.R. and A.T.; data curation, G.D.B., P.R. and A.T.; writing-original draft preparation, M.S.A.; writing-review and editing, M.P.L.M., N.C. and F.D.; visualization, N.C. and F.D.; supervision, N.C. and F.D.; project administration, N.C. and F.D.; funding acquisition, F.D. All authors have read and agreed to the published version of the manuscript.

Funding: This research received no external funding.

Institutional Review Board Statement: The study was conducted according to the guidelines of the Declaration of Helsinki, and approved by the Ethics Committee of A.O.U.P. Paolo Giaccone (protocol code 09/2021, October 2021).

Informed Consent Statement: Informed consent was obtained from all subjects enrolled for this study.

Data Availability Statement: The Data will be available upon reasonable request to the corresponding author.

Conflicts of Interest: The authors declare no conflict of interest.

\section{References}

1. Cucinotta, D.; Vanelli, M. WHO declares COVID-19 a pandemic. Acta Bio Med. Atenei Parm. 2020, 91, 157.

2. Robbiani, D.F.; Gaebler, C.; Muecksch, F.; Lorenzi, J.C.C.; Wang, Z.; Cho, A.; Agudelo, M.; Barnes, C.O.; Gazumyan, A.; Finkin, S. Convergent antibody responses to SARS-CoV-2 in convalescent individuals. Nature 2020, 584, 437-442. [CrossRef] [PubMed]

3. Lee, W.T.; Girardin, R.C.; Dupuis, A.P.; Kulas, K.E.; Payne, A.F.; Wong, S.J.; Arinsburg, S.; Nguyen, F.T.; Mendu, D.R.; FirpoBetancourt, A. Neutralizing antibody responses in COVID-19 convalescent sera. J. Infect. Dis. 2021, 223, 47-55. [CrossRef] [PubMed] 
4. $\quad$ Fenrich, M.; Mrdenovic, S.; Balog, M.; Tomic, S.; Zjalic, M.; Roncevic, A.; Mandic, D.; Debeljak, Z.; Heffer, M. SARS-CoV-2 dissemination through peripheral nerves explains multiple organ injury. Front. Cell. Neurosci. 2020, 14, 229. [CrossRef] [PubMed]

5. Dan, J.M.; Mateus, J.; Kato, Y.; Hastie, K.M.; Yu, E.D.; Faliti, C.E.; Grifoni, A.; Ramirez, S.I.; Haupt, S.; Frazier, A.; et al. Immunological memory to SARS-CoV-2 assessed for up to 8 months after infection. Science 2021, 371, eabf4063. [CrossRef] [PubMed]

6. Sattler, A.; Angermair, S.; Stockmann, H.; Heim, K.M.; Khadzhynov, D.; Treskatsch, S.; Halleck, F.; Kreis, M.E.; Kotsch, K. SARSCoV-2-specific $\mathrm{T}$ cell responses and correlations with COVID-19 patient predisposition. J. Clin. Investig. 2020, 130, 6477-6489. [CrossRef] [PubMed]

7. Riou, C.; Schäfer, G.; du Bruyn, E.; Goliath, R.T.; Stek, C.; Mou, H.; Hung, D.; Wilkinson, K.A.; Wilkinson, R.J. Rapid, simplified whole blood-based multiparameter assay to quantify and phenotype SARS-CoV-2 specific T cells. medRxiv 2020. [CrossRef]

8. Cossarizza, A.; Chang, H.-D.; Radbruch, A.; Acs, A.; Adam, D.; Adam-Klages, S.; Agace, W.W.; Aghaeepour, N.; Akdis, M.; Allez, M.; et al. Guidelines for the use of flow cytometry and cell sorting in immunological studies (second edition). Eur. J. Immunol. 2019, 49, 1457-1973. [CrossRef] [PubMed]

9. Smith, S.G.; Smits, K.; Joosten, S.A.; van Meijgaarden, K.E.; Satti, I.; Fletcher, H.A.; Caccamo, N.; Dieli, F.; Mascart, F.; McShane, H.; et al. Intracellular Cytokine Staining and Flow Cytometry: Considerations for Application in Clinical Trials of Novel Tuberculosis Vaccines. PLoS ONE 2015, 10, e0138042. [CrossRef] [PubMed]

10. Schwarzkopf, S.; Krawczyk, A.; Knop, D.; Klump, H.; Heinold, A.; Heinemann, F.M.; Thümmler, L.; Temme, C.; Breyer, M.; Witzke, O.; et al. Cellular Immunity in COVID-19 Convalescents with PCR-Confirmed Infection but with Undetectable SARS-CoV-2-Specific IgG. Emerg.Infect. Dis. 2021, 27. [CrossRef]

11. Kalimuddin, S.; Tham, C.Y.L.; Qui, M.; de Alwis, R.; Sim, J.X.Y.; Lim, J.M.E.; Tan, H.-C.; Syenina, A.; Zhang, S.L.; Le Bert, N.; et al. Early $\mathrm{T}$ cell and binding antibody responses are associated with COVID-19 RNA vaccine efficacy onset. Med 2021, 2, 682-688.e4. [CrossRef] [PubMed]

12. Bange, E.M.; Han, N.A.; Wileyto, P.; Kim, J.Y.; Gouma, S.; Robinson, J.; Greenplate, A.R.; Hwee, M.A.; Porterfield, F.; Owoyemi, O; ; et al. CD8+ T cells contribute to survival in patients with COVID-19 and hematologic cancer. Nat. Med. 2021, 27, 1280-1289. [CrossRef] [PubMed]

13. Herishanu, Y.; Avivi, I.; Aharon, A.; Shefer, G.; Levi, S.; Bronstein, Y.; Morales, M.; Ziv, T.; Shorer Arbel, Y.; Scarfò, L.; et al. Efficacy of the BNT162b2 mRNA COVID-19 vaccine in patients with chronic lymphocytic leukemia. Blood 2021, 137, $3165-3173$. [CrossRef] [PubMed]

14. Connolly, C.M.; Boyarsky, B.J.; Ruddy, J.A.; Werbel, W.A.; Christopher-Stine, L.; Garonzik-Wang, J.M.; Segev, D.L.; Paik, J.J. Absence of Humoral Response After Two-Dose SARS-CoV-2 Messenger RNA Vaccination in Patients with Rheumatic and Musculoskeletal Diseases: A Case Series. Ann. Intern. Med. 2021, 174, 1332-1334. [CrossRef] [PubMed]

15. Spiera, R.; Jinich, S.; Jannat-Khah, D. Rituximab, but not other antirheumatic therapies, is associated with impaired serological response to SARS- CoV-2 vaccination in patients with rheumatic diseases. Ann. Rheum. Dis. 2021, 80, 1357. [CrossRef] [PubMed]

16. Hagin, D.; Freund, T.; Navon, M.; Halperin, T.; Adir, D.; Marom, R.; Levi, I.; Benor, S.; Alcalay, Y.; Freund, N.T. Immunogenicity of Pfizer-BioNTech COVID-19 vaccine in patients with inborn errors of immunity. J. Allergy Clin. Immunol. 2021, 148, 739-749. [CrossRef] [PubMed]

17. Malipiero, G.; Moratto, A.; Infantino, M.; D’Agaro, P.; Piscianz, E.; Manfredi, M.; Grossi, V.; Benvenuti, E.; Bulgaresi, M.; Benucci, M.; et al. Assessment of humoral and cellular immunity induced by the BNT162b2 SARS-CoV-2 vaccine in healthcare workers, elderly people, and immunosuppressed patients with autoimmune disease. Immunol. Res. 2021, 1-8. [CrossRef] 